\title{
THE SURVIVAL STRATEGY OF HALAL TOURISM IN COVID-19 PANDEMIC ERA
}

\author{
Muawanah $^{1}$ \\ Institut Pesantren KH. Abdul Chalim Mojokerto \\ anadarto54@gmail.com \\ Nur Dinah Fauziah ${ }^{2}$ \\ Institut Pesantren KH.Abdul Chalim Mojokerto \\ dina.fau@gmail.com \\ Mohamad Toha ${ }^{3}$ \\ Institut Pesantren KH.Abdul Chalim Mojokerto \\ motoha013@gmail.com \\ Agnes Cahyatria Manaku ${ }^{4}$ \\ Institut Pesantren KH Abdul Chalim Mojokerto \\ agnesmanaku99@gmail.com
}

\begin{abstract}
Halal tourism has great potential for the Indonesian economy and is currently trying to defend its sector from the Covid-19 or corona virus outbreak. Covid-19 is one of the outbreaks that has been declared a pandemic because it is a global disease spreading very quickly. Covid-19 is a new virus originated in Wuhan, China in 2019 and has spread to almost all countries in the world, including Indonesia. The impact of this virus is felt by everyone in the world. It even threatens all sectors that affect the economy. Among these sectors is halal tourism. Therefore, the halal tourism sector is currently preparing a strategy to stay afloat even in situations and conditions like this as a preparation for the post-Covid19. The strategy of the Indonesian state in maintaining halal tourism is to prioritize improving destinations, preparing budget support from cooperation with halal tourism, providing mitigation SOPs, strengthening regulations for tourists from abroad entering Indonesia.

Keywords: Halal tourism, Covid-19, Sharia Economy.

Abstrak

Pariwisata halal sangat berpotensi bagi perekonomian Indonesia dan saat ini sedang berusaha mempertahankan sektornya dari wabah Covid-19 atau corona virus. Covid-19 adalah salah satu wabah yang telah dinyatakan sebagai pandemi karena merupakan suatu penyakit global yang penularannya sangat cepat. Covid-19 merupakan virus baru yang berasal dari Wuhan, China pada tahun 2019 silam dan sudah menyebar hampir ke seluruh negara di dunia, tak terkecuali Indonesia. Dampak dari adanya virus ini dirasakan oleh semua orang di dunia, tak hanya itu bahkan mengancam seluruh sektor yang mempengaruhi perekonomian. Diantara sektor itu adalah pariwisata halal. Oleh karena itu saat ini sektor pariwisata halal tengah menyiapkan strategi untuk tetap bertahan meskipun dalam situasi dan kondisi seperti ini juga sebagai persiapan menghadapi pasca Covid-19. Strategi negara Indonesia dalam mempertahankan pariwisata halal adalah memprioritaskan pada pembenahan destinasi, mempersiapkan dukungan anggaran dari kerja sama dengan pariwisata halal, menyediakan SOP mitigasi, menguatkan regulasi wisatawan dari luar negeri yang masuk ke Indonesia.
\end{abstract}

Kata Kunci: Pariwisata halal, Covid-19, Ekonomi Syariah. 


\section{INTRODUCTION}

Coronavirus is a group of viruses that can cause disease in animals or humans. Several types of coronavirus are known to cause respiratory infections in humans ranging from colds to more serious coughs such as Middle East Respiratory Syndrome (MERS) and Severe Acute Respiratory Syndrome (SARS). The newly discovered coronavirus causes the disease COVID19. COVID-19 is an infectious disease caused by a newly discovered type of coronavirus. This is a new virus and a previously unknown disease prior to the outbreak in Wuhan, China, in December 2019 (WHO, 2020).

A pandemic is a global disease outbreak. According to the World Health Organization (WHO), a pandemic is declared when a new disease spreads around the world beyond borders. A pandemic refers to a disease spreading to many people in several countries at the same time. The last pandemic that occurred in the world was in 2009 due to swine flu which killed hundreds of thousands of people. The characteristics of a pandemic include: a new type of virus, infecting many people easily, and spreading among humans efficiently. The corona virus has these three characteristics. Therefore, WHO has currently determined that the Covid-19 or corova virus is a pandemic.

Covid-19 has a profound impact not only on humans but on sectors in every country that has this case. The most potentially affected one is on the economy. Originating from Wuhan, China, Covid-19 turned out to be very bad for the developed country known for the biggest economic power in the world. This case is felt not only by China but also all affected countries.

Indonesian government data shows that the largest area of Covid-19 distribution is on the island of Java. Five provinces in Indonesia with the highest cases, namely: DKI Jakarta $(227,365$ cases) West Java (112,587 cases) Central Java (102,904) East Java (99,377 cases) South Sulawesi (41,036 cases) (Kompas.com, 2020).

The concept of halal/ sharia tourism is a process of integrating natural values into all aspects of tourism activities. Indonesia itself in developing halal tourism adopts the Global Muslim Travel Index criteria as a reference for halal tourism development.

The spread of Covid-19 causes a decrease in the number of tourists, especially in the halal tourism sector, caused by a decrease in the number of foreign tourists visiting Indonesia and local tourists. 
Based on data from the world travel and tourism council, WTTC, the real impact on the travel and tourism sector due to the corona virus is that it has the potential to cause 50 million people worldwide to lose their jobs. The Indonesian Ministry of Manpower and Transmigration reported that until 2 June 2020 as many as 3.05 million Indonesian workers were affected by the corona virus. In addition, it is estimated that there will be an additional 5.23 million unemployed if it is widespread. Data from the Indonesian Hotel and Restaurant Association (PHRI) noted that until early April 2020 there were around 1,266 hotels closed due to the corona virus and 150,000 employees are now being laid off due to sluggish business. PHRI predicts that the potential loss of the Indonesian tourism industry due to the corona virus outbreak reaches US $\$ 1.5$ billion or the equivalent of Rp. 21 trillion (Fathurrahim, 2020).

Therefore, in this article, we will explain further how the halal tourism's strategy is in the the Covid-19 pandemic era.

\section{RESULTS AND DISCUSSION}

\section{Corona Virus (Covid-19)}

Corona virus causes common cold to more severe illnesses such as Middle East respiratory syndrome (MERS-CoV) and severe acute respiratory syndrome (SARS-CoV). Corona viruses are zoonotic, which means they are transmitted between animals and humans. Based on data from the Indonesian Ministry of Health, the development of the Covid-19 case in Wuhan began on September 30, 2019, in which the Wuhan Municipal Health Committee issued a statement "urgent notice on the treatment of pneumonia of unknown cause" (Sarip, Syarifudin, \& Muaz, 2020).

The following is the number of patients with Covid-19 infection cases in the world, showing the trend of transmission rates is still increasing. Launching data from the Worldometers page, until Tuesday (19/1/2021) morning, the total confirmed cases of Covid-19 in the world were 95,966,527 cases. Of these, 68,545,627 patients have recovered, and 2,048,171 people have died. There are currently 25,372,729 active cases, with details of 25,260,887 patients with mild conditions and 111,842 in serious conditions. Meanwhile, Covid-19 cases in 10 countries with the most Covid-19 cases 1 . United States: 24,611,484 cases, 408,491 people died, total recovered 14,536,845 2. India: 10,582,647 cases, 152,593 people died, total recovered 10,227,852 3. Brazil: 3,591,066 cases, 210,299 people died, total recovered 7,411,654 4. Russia: 3,520,531 cases, 66,037 people died, total recovered 2,978,764 5. England: 3,433,494 cases, 
89,860 people died completely healed 1,546,575 6. France: $2,914,725$ cases, 70,686 people died, 210,200 total recovered 7. Turkey: 2,392,963 cases, 24,161 people died, total recovered 2,270,769 8. Italy: 2,390,101 cases, 82,554 people died, total recovered 1,760,489 9. Spain: 2,336,451 cases and 53,769 people died. 10 . Germany: 2,059,314 cases, 48,105 people died, total cured 1,691,700 (WHO, 2020).

The increase in cases of corona virus infection has also occurred in Indonesia. The latest data until Sunday (17/1/2021), Covid-19 cases in Indonesia totaled more than 900,000 cases. In Southeast Asia, cases in Indonesia are the highest. The following is the record of Covid-19 cases in Southeast Asia quoted from Worldometers data, Monday afternoon: 1. Indonesia Total cases: 907,929 Cured: 736,460 Deaths: 25,987 2. Philippines Total cases 500,577 Cured: 465,991 Died: 9,895 3. Malaysia Total cases: 158,434 Cured: 120,051 Deaths: 601 4. Myanmar Total cases: 134,318 Cured: 117,663 Deaths: 2,955 5. Singapore Total cases: 59,113 Cured: 58,846 Died: 29 6. Thailand Total cases: 12,054 Cured: 9,015 Died: 70 7. Vietnam Total cases: 1,537 Cured: 1,380 Died: 35 8. Cambodia Total cases: 439 Cured: 385 Died: 0 9. Brunei Darussalam Total cases: 174 Cured: 168 Died: 3 10. Laos Total cases: 39 Cured: 26 Died: 0 11. Timor Leste Total cases: 31 Cured: 30 Died: 0 (Kompas.com, 2020).

The impact of the Covid-19 outbreak can be seen in almost all sectors of public life. Social activities are prohibited and temporarily suspended, the economy is weakening, transportation services are reduced and strictly regulated, tourism is closed, shopping centers are empty of visitors and informal sectors such as; Online motorcycle taxis, public transportation drivers, street vendors, traveling traders, MSMEs and rough porters decrease income. Trade centers, such as malls, Tanah Abang market which are usually crowded with people have suddenly become quiet and are currently temporarily closed. The tourism sector has experienced a decline, the government has closed tourist attractions and entertainment venues. Work and study are also carried out at home online (Syafrida \& Hartati, 2020).

The existence of Covid 19 forces the government to issue policies relating to emergencies, often known as Government Regulations in Lieu of Laws (Perpu). The policies are expected to overcome the effects that occur due to the existence of Covid 19. 


\section{Halal Tourism}

Halal tourism has been known since 2015 when a World Halal Tourism Summit (WHTS) event was held in Abu Dhabi, UAE. Previously, the tourism world only knew as Muslim Tour or the like. In this event, WHTS tried to realize that the market share of halal tourism is very large and needs to be developed. In several major countries, the terminology of halal tourism uses terms such as Islamic tourism, halal tourism, halal travel, halal lifestyle, or as a Muslim friendly destination. From an industrial perspective, halal tourism is a complementary product and does not eliminate conventional tourism types. As a new way to develop Indonesian tourism that upholds Islamic culture and values without eliminating the uniqueness and originality of the region (Kemenparekraf, 2015).

Halal tourism is extend services. If there is no search, if there is, it can make you feel comfortable. Halal tourism can go hand in hand with others. It can be complementary, it can be a product itself. For example, there is a halal hotel, which means that people looking for hotels that guarantee the halalness of their products will get wider options. This actually expands the market, not reduces it. From what was not there before, so there is. According to (Hamzah and Yudiana), the difference between conventional, religious, and sharia or halal tourism can be seen in the following table (Andriani, 2015):

Table 1

Comparison of Conventional, Religious, and Halal Tourism

\begin{tabular}{|l|l|l|l|l|}
\hline No & $\begin{array}{c}\text { Comparison } \\
\text { Items }\end{array}$ & \multicolumn{1}{|c|}{$\begin{array}{c}\text { Conventional } \\
\text { Tourism }\end{array}$} & Religious Tourism & Halal Tourism \\
\hline 1 & Object & $\begin{array}{l}\text { Nature, culture, } \\
\text { culinary, heritage }\end{array}$ & $\begin{array}{l}\text { Places of Worship, } \\
\text { Historical Relics }\end{array}$ & All \\
\hline 2 & Purpose & Entertaining & $\begin{array}{l}\text { Increasing } \\
\text { Spirituality }\end{array}$ & $\begin{array}{l}\text { Enhancing } \\
\text { Spirituality in } \\
\text { entertaining } \\
\text { ways }\end{array}$ \\
\hline 3 & Target & $\begin{array}{l}\text { Touching the pleasures } \\
\text { and pleasures of the } \\
\text { dimension of lust, } \\
\text { solely for } \\
\text { entertainment }\end{array}$ & $\begin{array}{l}\text { Spiritual aspects that } \\
\text { can calm the soul in } \\
\text { order to find peace } \\
\text { of mind }\end{array}$ & $\begin{array}{l}\text { Fulfilling desires } \\
\text { and pleasures } \\
\text { and fostering } \\
\text { religious } \\
\text { awareness }\end{array}$ \\
\hline
\end{tabular}




\begin{tabular}{|c|c|c|c|c|}
\hline 4 & Guide & $\begin{array}{l}\text { Comprehending and } \\
\text { mastering information } \\
\text { so that it can attract } \\
\text { tourists to tourist } \\
\text { objects }\end{array}$ & $\begin{array}{l}\text { Mastering the } \\
\text { history, character } \\
\text { and location of } \\
\text { tourist objects }\end{array}$ & $\begin{array}{l}\text { Make tourists } \\
\text { interested in } \\
\text { objects as well as } \\
\text { evoke the } \\
\text { religious spirit of } \\
\text { tourists. Able to } \\
\text { explain the } \\
\text { function and role } \\
\text { of sharia in the } \\
\text { form of } \\
\text { happiness and } \\
\text { inner satisfaction } \\
\text { in human life }\end{array}$ \\
\hline 5 & $\begin{array}{l}\text { Worship } \\
\text { Facilities }\end{array}$ & Just a complement & Just a complement & $\begin{array}{l}\text { Becoming an } \\
\text { integral part of } \\
\text { tourism objects } \\
\text { and the vacation } \\
\text { package }\end{array}$ \\
\hline 6 & Culinary & General & General & $\begin{array}{l}\text { Specifics which } \\
\text { are Halal }\end{array}$ \\
\hline 7 & $\begin{array}{l}\text { Relations with } \\
\text { the community } \\
\text { in the tourism } \\
\text { object }\end{array}$ & $\begin{array}{l}\text { Complementary and } \\
\text { only for material gain }\end{array}$ & $\begin{array}{l}\text { Complementary and } \\
\text { only for material } \\
\text { gain }\end{array}$ & $\begin{array}{l}\text { Integral, } \\
\text { interaction based } \\
\text { on sharia } \\
\text { principles }\end{array}$ \\
\hline 8 & Travel Agenda & Every time & Certain Times & $\begin{array}{l}\text { Paying attention } \\
\text { to time. }\end{array}$ \\
\hline
\end{tabular}

Source: (Hamzah and Yudiana, 2015)

Halal tourism is part of the tourism industry aimed at Muslim tourists. Tourist services in halal tourism refer to Islamic rules. Examples of halal tourism concepts such as every product and service are designed to meet the needs of Muslim tourists. Starting from halal restaurants (not selling non-halal food / drinks), halal lodging, and so on. This provision applies universally in all countries. A tourist destination that can be said as halal tourism is that it must meet the main needs of Muslim tourists, as quoted from Crescent Rating, as a company that focuses on developing halal tourism that has conducted studies in 130 countries, showing 6 basic needs of Muslim tourists, namely: 1) Food halal. Free of alcohol, pork, and the like; 2) Availability of worship facilities; 3) Bathroom with water for ablution; 4) Services during the month of Ramadan, for example iftar meals and sahur 5) Inclusion of non-halal labels if there is food that is not halal 6) Recreational facilities that maintain privacy, do not mix freely. 
The concept of halal/ sharia tourism is a process of integrating natural values into all aspects of tourism activities. The value of Islamic law as a belief held by Muslims is a basic reference in building tourism activities. Sharia tourism considers the basic values of Muslims in its presentation, from accommodation, restaurants, to tourism activities that always refer to Islamic norms. The concept of Sharia tourism is the actualization of the concept to Islam where the value of halal and haram is the main measure, it means that all aspects of tourism activities cannot be separated from halal certification which must be a reference for every tourism actor.

Indonesia in developing halal tourism adopts the Global Muslim Travel Index criteria as a reference for halal tourism development. For this reason, an agency under the auspices of the Ministry of Tourism of the Republic of Indonesia was formed which has the authority and responsibility for regulating tourism in Indonesia, a special agency called the Halal Tourism Development Acceleration Team (TP3H), a team that is given the authority to help the government map, develop and provide regional guidelines has the potential to develop halal tourism, this team then formed three general criteria in developing halal tourism (Widagdyo, 2015).

Meanwhile, the Global Muslim Travel Index (GMTI), a standard compiled by Crescent Rating, has also succeeded in identifying halal tourism standards in the world as follows (Zulfikar, 2019): 1) Family Friendly Destinations; 2) The tourist destination must be family and child friendly; 3) Public safety for Muslim tourists; 4) The number of Muslim tourist arrivals is quite crowded; 5) Services and Facilities at Muslim-Friendly Destinations; 6) Choices of food that are guaranteed to be halal; 7) Easy access to worship and in good condition; 8) Facilities at the airport which are Muslim friendly; 9) Adequate accommodation options; 10) Halal Awareness and Destination Marketing; 11) Ease of communication; 12) Reach and awareness of the needs of Muslim tourists; 13) Air transport connectivity 14) Visa requirements.

The 10 halal tourist destinations from various regions in Indonesia are (Salim, 2017): 1). West Nusa Tenggara, there are tours such as Gili Trawangan and Mount Rinjani and others; 2) Aceh, there are tours such as the Banda Aceh Museum to the center of Islamic culture; 3) West Sumatra, there are tourist destinations being promoted, namely Lake Singkarak, Mentawai Islands; 4) East Java, tourist destinations such as Bromo and Semeru are predicted to be the mainstay spots for halal tourism; 5) Central Java, the tourism potential is very large, such as Karimun Jawa; 6) East Kalimantan, Berau Regency is being intensively being promoted as a 
halal tourist destination; and further areas that have the potential to become halal tourism destinations are 7) Yogyakarta; 8) South Sulawesi; 9) South Sumatra; 10) Banten.

As the effort to develop halal tourism, Indonesia is trying to increase the existence of Islamic hotels. The government through the Regulation of the Minister of Tourism and Creative Economy of Indonesia has made guidelines for the operation of sharia hotels. Sharia referred to here is the principles of Islamic law as regulated by fatwas and / or has been approved by the Indonesian Council of Ulama (MUI). Indonesia is synergizing with many parties to develop halal tourism, for example the Ministry of Tourism, which collaborates with the National Sharia Council (DSN), the Indonesian Council of Ulama (MUI) and the Business Certification Institute (LSU). The concrete form of this collaboration is by developing tourism and promoting culture and religious values which will then be outlined in the Regulation of the Minister of Tourism and Creative Economy. In developing halal tourism, the main paradigm that needs to be understood together is that halal tourism does not aim to alienate Muslim tourists from general tourism activities, or to limit non-Muslim tourists to certain tourist destinations. The development of halal tourism aims to provide comfort for Muslim tourists in carrying out worship according to religious law while traveling. At the same time, for non-Muslim tourists, halal tourism is expected to provide safe and healthy tourism services as well as to introduce Islamic teachings as a universal value.

Halal tourism is very influential on the economy and can even be said to have a very significant relationship. When halal tourism is growing rapidly in an area, it will be able to complement the regional economic growth if it is supported by increasingly advanced tourism. And it is not only profitable for big entrepreneurs but also small business actors, interrelated with their uses and benefits of each other.

\section{Al-Qur'an verses on Halal Tourism}

In Al-Qur'an, many verses about tourism are explained including Surah Quraish verses 1-4:

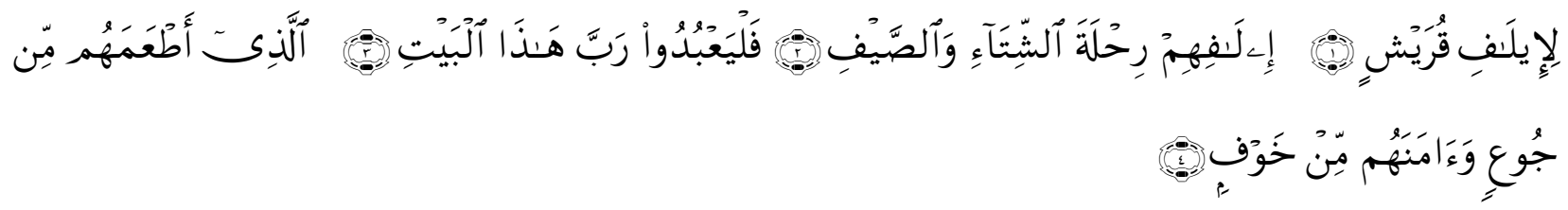

"For the covenants (of security and safeguard enjoyed) by the Quraish, Their covenants (covering) journeys by winter and summer,- Let them adore the Lord of this House, Who provides them with food against hunger, and with security against fear (of danger)." 
Surah Al - An'am: verse 11:

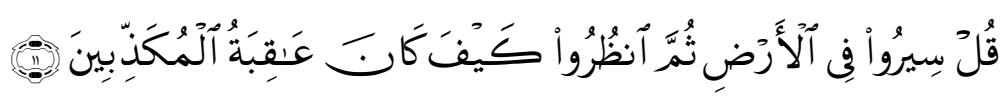

Say, "Travel throughout the land and see the fate of the deniers."

And Surah An-Nisa verse 100:

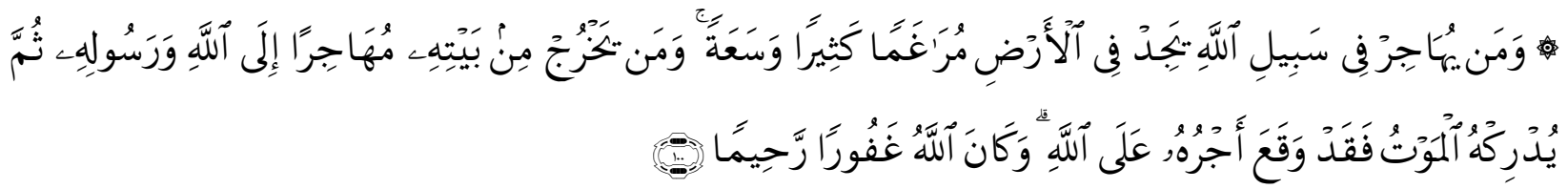

"Whoever emigrates in the cause of Allah will find many safe havens and bountiful resources throughout the earth. Those who leave their homes and die while emigrating to Allah and His Messenger-their reward has already been secured with Allah. And Allah is All-Forgiving, Most Merciful."

\section{Halal Tourism and Covid-19}

The impact of tourism on the economy can generally be a source of foreign exchange, a source of income for the community, income for the government, creating jobs, the effect on prices and tariffs, the effect on the distribution of profits and benefits, the influence on management and ownership, and of course it can affect development. There are several things that can affect tourism-related income, including the level of consumption or expenditure, distance from tourist attractions, years of service and the number of tourists visiting.

In the midst of the Covid-19 outbreak, the halal tourism industry has been the most affected by the pandemic. In the midst of a situation like this, it is hoped that all industry players can collaborate in order to reduce the negative impact on business. The impact of Covid-19 is extraordinary. The effect on halal tourism is of course the same as the tourism industry in general. Therefore, the industry has to focus on the rescue side first. Industry players need to find ways to survive conditions of minimal demand while maintaining tourism human resources.

Currently, the halal tourism sector, both the world and Indonesia, is experiencing a crisis due to the impact of the Covid-19 outbreak. Apart from halal tourism, this impact is felt by the service industry, such as travel agents, domestic and international flights, hotels and restaurants. Everyone feels it. Halal travel agents to other affected cities or countries are no longer sold, this has resulted in a drastic decrease in the income of each related business. This is especially true 
for countries that make halal tourism a major contribution to Gross Domestic Product, including China, Spain, Italy, Germany, Britain, America, France, Iran, and Indonesia.

By implementing physical distancing and the rules for large-scale social restrictions (PSBB), a number of industrial sectors, especially the halal industry sector, suffered losses. The halal industry sector that has suffered major losses is the tourism sector because the tourism sector is an industry whose income depends on the number of people or tourists visiting. On the one hand, the government prohibits large crowds of people in one place in order to prevent the spread of Covid-19. Thus, the tourism industry is one of the industries that has suffered losses due to the Covid-19 pandemic.

The Indonesian Minister of Tourism and Creative Economy described the losses experienced by the tourism sector, which last year and now are very different. The potential from last year's foreign exchange was approximately $20 \%$ billion dollars. This year, it cannot be predicted, it could be halved or more if foreign exchange lost from halal tourism. For tourists, it is very different from the previous year which consisted of around 16 million tourists. This year, it is only estimated that it will reach 5 million tourists or even smaller (Prasetia, 2020).

\section{Survival Strategies of Halal Tourism in the Covid 19 Outbreak}

After all, this halal tourism business actor must prepare a strategy or way to deal with this crisis, especially with the situation getting worse and the Covid-19 outbreak cannot be predicted when it will end. Although some parties believe that everything will return to normal and recover in 2021, it is still very important for now to maintain business. It takes a very long process as if starting from scratch to restore the situation. Following the process of restoring things to their original state takes time, but time continues, it remains only how each business actor can create a strategy to survive even in these situations and conditions because this will make it easier for business actors to be ready to face the post-pandemic process later.

In Indonesia, business players in the halal tourism sector have prepared a strategy to survive the Covid-19 outbreak even though they still suffer losses, at least this sector is not dead. The strategies prepared include:

The first, the halal tourism sector will only focus more on improving destinations. Tourist destinations will affect the comfort of tourists such as cleanliness, safety, health, environmental preservation, regional regulations, halal tourism services, and so forth which will have a positive impact on halal tourism. This strategy is also a preparation for the post-pandemic period where 
people will release their fatigue in the house for days or even months due to various government regulations and recommendations to stay at home.

The second, the budget support related to cooperation with hotels, tourist transportation, halal food and beverage companies, and others related to halal tourism. It is necessary to explain to the public the form of cooperation that will be carried out, whether it is purely like the procurement of goods and services (business contracts) or a pure form of social care from the business owners carried out as a form of contribution to a country in the midst of this crisis.

The third, strengthen the SOP for mitigating halal tourism by still referring to the standardization provided by WHO. The need for this SOP is prepared early on during this pandemic so that when the post-pandemic period is only the implementation needs to be maximized.

The fourth, strengthening regulations for the entry of tourists from abroad. Halal tourism in Indonesia also very much sees Indonesia as a country that has many halal tourist destinations. Tourists from countries/ regions that have or are prone to disease outbreaks must go through a very strict selection to obtain entry permits/ visas to Indonesia. Currently, it is not only Indonesia that imposes large-scale social restrictions, but also from other countries. However, there is nothing wrong if this is still being prepared and will also be urgently needed after the pandemic (Republika, 2020).

Another alternative which can be tried is to shift the tourism business to other sectors that have demand, for example hotels or accommodation can be used as self-isolation services. This offer can target the segment of the old who live alone without a family. However, this service still needs to be further studied by considering market demand and operational capacity, including the readiness of supporting facilities and infrastructure.

Halal tourist objects such as hotels which are the resting place for the tourists are in fact very threatened by this pandemic, but several halal hotels or sharia hotels have made new breakthroughs to survive in the Covid-19 pandemic. This is an alternative to the tourism business, namely by diverting to halal hotels that have demand, such as hotels that will be used as the self-isolation services. It applies to every visitor. Apart from that, there is a massive promotion by offering packages to stay at hotels for days or even months at a price that is very far from the market price in order to get visitors. The vouchers given are valid either during a pandemic or post-pandemic. Because even though after the pandemic this hotel will be very 
necessary for tourists. Thus, during the post-pandemic the hotel is no longer quiet and can operate normally.

According to the National Committee for Sharia Economics and Finance (KNEKS), even though it has a tremendous impact, the halal tourism sector must remain focused on the rescue side first how industrial entrepreneurs can survive in conditions of minimal demand while maintaining tourism human resources, such as taking advantage of the hospitality activities described above are quite helpful. Halal tourism needs to collaborate, open up as much information as possible with other stakeholders and find out which possibilities for collaboration. There needs to be a further study by considering market demand and operational capacity, including the readiness of supporting facilities and infrastructure (Puspaningtyas, 2020).

Therefore, halal tourism during the pandemic or post-Covid-19, tour organizers, tour service bureaus or tourists themselves must comply with health protocols having been determined by the government or tourist destinations. By following health protocols aiming to break the chain of transmission of the virus and tourists remain in healthy condition, after returning from a tour. The convenience of traveling in this new era is not as free as in the normal era. However, this reality must be faced, for that awareness of complying with health protocols, starting from the selection of vehicles, destination locations, equipment that must be carried and compliance with the signs that have been installed must be carried out in an orderly manner.

The key to successful group travel lies in the travel agency/ tour guide, which makes tour plans in a professional manner. The Muslim tourists can have fun, without leaving the obligation of worship and stay away from the prohibitions existing in the guidance of Islam, and stay healthy. Meanwhile, halal tourism managers must also maintain health protocols by limiting the number of visitors and maintaining distance or limiting direct interaction with visitors, as well as maintaining the cleanliness of tourist facilities and infrastructure.

\section{CONCLUSION}

During the Covid-19 outbreak, the halal tourism industry has been most affected by the pandemic. In the midst of the situation, it is hoped that all industry players can collaborate in order to reduce the negative impact on business. The impact of Covid-19 is extraordinary, the effect on halal tourism is of course the same as the tourism industry in general. The industry has to focus on the rescue side first. Industry players need to find ways to survive conditions of minimal demand while maintaining tourism human resources. 
One alternative that can be tried is to shift the tourism business to other sectors that have demand, for example hotels or accommodation can be used as self-isolation services. This offer can target the segment of the old living alone without a family. However, this service still needs to be further studied by considering market demand and operational capacity, including the readiness of supporting facilities and infrastructure. In Indonesia, a strategy in maintaining halal tourism includes: prioritizing destination improvement, preparing budget support from cooperation with halal tourism, providing mitigation SOPs, strengthening regulations for foreign tourists entering Indonesia.

\section{REFERENCES}

Andriani. Dini. (2015). Laporan Akhir Kajian Pengembangan Pariwisata Syariah. Asisten Deputi Penelitian dan Pengembangan Kebijakan Kepariwisataan Deputi Bidang Pengembangan Kelembagaan Kepariwisataan Kementerian Pariwisata, Jakarta.

Kementerian Pariwisata RI. (2015). Laporan Akhir Kajian Pengembangan Wisata Syariah. Jakarta: Kementerian Pariwisata RI.

Prasetia, A. (2020, April 23). Data Efek Virus Corona ke Wisata RI per 23 April 2020. Retrieved May 19, 2020, from Detik: https://travel.detik.com.

Puspaningtyas, L. (2020, April 14). KNEKS Imbau Industri Pariwisata Halal Berkolaborasi. Retrieved January 20, 2021, from Republika: https://republika.co.id/

Salim, M. G. (2017, November 08). Tempat-Tempat Wisata Halal Indonesia ini adalah Salah Satu Program Kementerian Pariwisata. Retrieved January 20, 2021, from Brilio: https://www.brilio.net/

Sarip, Syarifudin, A., \& Muaz, A. (2020). DAMPAK COVID-19 TERHADAP PEREKONOMIAN MASYARAKAT . l-Mustashfa: Jurnal Penelitian Hukum Ekonomi Islam , 10-20.

Satriana, Eka Dwi \& Durrotul, Hayyun. (2018). "Halal Tourism: Development, Chance and Challenge”, Jurnal Of Halal Product and Research (JHPR), Vol.01 No.02.

Syafrida, \& Hartati, R. (2020). Bersama Melawan Virus Covid 19 di Indonesia. SALAM; Jurnal Sosial \& Budaya Syar-i , 495-508.

Subrakah, Alwafi Ridho. (2018) "Potensi dan Prospek Wisata Halal Dalam Meningkatkan Ekonomi Daerah", Jurnal Sospol,Vo.4 No.2.

Widagdyo, K. G. (2015). Analisis Pasar Pariwisata Halal di Indonesia. Tauhidinomics: Journal of Islamic Banking and economics, 73-80.

Zulfikar, F. (2019, April 13). Wisata Halal? Apa sih Artinya. Retrieved January 19, 2020, from good news from Indonesia: https://www.goodnewsfromindonesia.id/ 